\title{
Volcanism of the South Aegean Volcanic Arc
}

Georges E. Vougioukalakis1, Christopher S. Satow2, and Timothy H. Druitt3

\begin{abstract}
Volcanism along the South Aegean Volcanic Arc began about 4.7 Ma and has lasted until the present day, with eruptions at Methana, Milos, Santorini, Kolumbo and Nisyros Volcanoes in historical times. These volcanoes can be grouped into five volcanic fields: three western fields of small, mostly monogenetic edifices, and two central/eastern fields with composite cones and calderas that have produced large explosive eruptions. Crustal tectonics exerts a strong control over the locations of edifices and vents at all five volcanic fields. Tephra and cryptotephra layers in deep-marine sediments preserve a continuous record of arc volcanism in the Aegean as far back as 200,000 years. Hazards from the volcanoes include high ash plumes, pyroclastic flows and tsunamis. Monitoring networks should be improved and expanded.
\end{abstract}

Keywords: Aegean Sea, Magmatic arc, volcanology, volcanotectonics, tephrostratigraphy

\section{INTRODUCTION}

The South Aegean Volcanic Arc lies in the densely populated Eastern Mediterranean region, the cradle of western civilization. Subduction of the African plate beneath Europe occurs along the Hellenic trench south of the arc, causing partial melting of the mantle wedge and magma genesis. Although the plate convergence rate is one of the lowest in the world, rollback of the subducted slab has caused strong extension of the back-arc region, making the Aegean one of the most rapidly deforming, and most seismically active, sectors of the

\footnotetext{
1 Institute for Geology and Mineral Exploration,

3rd exit Olympic Village

13677, Aharne, Athens, Greece

E-mail: gvoug@igme.gr

2 Department of Social Sciences

Gibbs Building

Oxford Brookes University

Headington Road, Oxford, OX3 0BP, UK

E-mail: csatow@brookes.ac.uk

3 Clermont Auvergne University, CNRS, IRD, OPGC

Laboratory Magmas-Volcanoes

F-63000 Clermont-Ferrand, France

E-mail: T.Druitt@opgc.univ-bpclermont.fr
} 
Alpine-Himalayan belt. Volcanic centres of the arc include Santorini, a major international tourist centre famous for its Late Bronze Age explosive eruption which buried a thriving contemporary town and may have impacted the Minoan civilization on the island of Crete. Kolumbo seamount, NE of Santorini, erupted in 1650, and its submarine caldera today hosts a high-temperature hydrothermal system and an associated diverse marine ecosystem. The huge pyroclastic flows of the Kos Plateau Tuff eruption 161,000 years ago in the eastern sector of the arc travelled large distances to neighbouring islands, possibly across the sea. Several volcanoes have hot hydrothermal systems and fumarolic fields, and five have erupted in historical times. Early studies at Santorini were pivotal in the development of some concepts of modern volcanology, such as how calderas form. Details of these different aspects of the arc are provided in other articles of this issue. Here, we provide an overview of the volcanoes making up this unique and fascinating island arc, their deep-sea tephra records, their relationships to regional tectonics, their natural resources, and their hazards.

\section{THE SOUTH AEGEAN VOLCANIC ARC}

Magmatism related to the Hellenic convergence zone began in northern Greece in the Oligocene, where it generated a broad belt of calc-alkaline volcanism. This belt then shifted southwards in the Early Miocene due to slab rollback, before moving to the site of the present-day arc in the Pliocene. The effect of rollback was, from the late Miocene onwards, overprinted by the production of a wide variety of K-rich magmas across the central Aegean (alkali basalts, shoshonites, trachytes, rhyolites) as a result of complex combinations of backarc spreading, slab detachment events, and ascent and decompression of deep asthenospheric mantle through slab tears along the western and eastern Aegean margins (Pe-Piper and Piper 2007).

The tholeiitic to calc-alkaline magmatism of the modern volcanic arc began 4.7 Ma (FIGS. 1 and 2). It includes, from west to east, five distinct volcanic fields: Sousaki; Aegina-MethanaPoros (also called Saronikos); Milos; Christiana-Santorini-Kolumbo; and Kos-Nisyros-Yali (Fytikas and Vougioukalakis 2005) (FIG. 1A).

\section{Sousaki Volcanic Field}

Sousaki is a small $\left(<1 \mathrm{~km}^{3}\right)$ volcanic field consisting mainly of dacitic lava domes and flows scattered across a large area (FIG. 1D). The oldest centres (4.1-3.6 Ma) occur in the west of the field, and the youngest ones (2.7-2.3 Ma) in the east. Minor explosive activity is recorded as dacitic to rhyolitic tephra layers in nearby lake sediments. Hydrothermal fluids have resulted in extensive argillization and silicification of the rocks, and in low-temperature (35$45^{\circ} \mathrm{C}$ ) fumaroles. 


\section{Aegina-Poros-Methana Volcanic Field}

The Aegina-Poros-Methana volcanic field occurs in the Gulf of Saronikos, a graben that has been active since the Pliocene (FIG. 1E). From 4.7 Ma to $4.3 \mathrm{Ma}$, shallow-marine eruptions at Aegina emplaced pillow lavas and tuffs. Then, from 3.9 Ma to 3.0 Ma (the main phase of activity), extrusion of andesitic to dacitic magmas built up lava domes and flows in a mainly subaerial environment. Following a period of low volcanic output, activity restarted with the eruption of subaerial andesitic and basaltic-andesitic lavas at 2.1-2.0 Ma. Palaeomagnetic studies have shown that the most recent volcanic products correlate with the Pleistocene part of the Matuyama polarity epoch and that Aegina has been inactive for the last $0.72 \mathrm{My}$ (Morris 2000). Poros Island has a single andesitic lava dome 3.1-2.6 My old. Methana Peninsula hosts the youngest products of the volcanic field, mostly 3.6 to $0.2 \mathrm{Ma}$, comprising dacitic to andesitic lava domes and block-and-ash flows. Although an accurate reconstruction of Methana's volcanic history is difficult because there are no distinctive marker beds, the available data favours a low, continuous rate of activity throughout the Quaternary. A historical eruption at Methana in about 230 BCE formed an andesitic lava dome (FIG. 3A) (Pe-Piper and Piper 2013). Other young volcanic centres occur a few kilometres offshore NW of Methana. The absence of marine sedimentary cover suggests a possible historical age for these centres (Foutrakis and Anastasakis 2018)

\section{Milos Volcanic Field}

The Milos volcanic field comprises the islands of Milos, Kimolos, Polyegos and Antimilos, as well as the Ananes islets (FIG. 1B). The field consists of scattered vents and edifices. The only composite volcano occurs on Antimilos. Milos, Kimolos and Polyegos are composed mainly of lava domes extruded through thick volcaniclastic deposits of submarine and subaerial origins (Stewart and McPhie 2006; Francalanci et al. 2007). The oldest products of the volcanic field have been $\mathrm{K}-\mathrm{Ar}$ dated at $3.5 \mathrm{Ma}$ on Milos. Biostratigraphy, magnetostratigraphy, and astronomical polarity timescale correlations of marine sediments deposited prior to volcanism in southern Milos give similar ages (4.5-3.7 Ma) (Van Hinsbergen et al. 2004), although it is unclear whether tephra layers (6.0-4.6 Ma) underlying these sediments derive from earlier Milos activity or from more northerly Aegean centres, such as Antiparos and Patmos, that were active at this time.

From 3.5 to $1.6 \mathrm{Ma}$, submarine (and locally subaerial) explosive and extrusive activity built up Ananes, Kimolos, Polyegos and most of Milos (FIG. 3C). Quaternary activity was concentrated in central Milos in three periods: (1) a large rhyolitic lava field (1.1-0.9 Ma), (2) the Trachylas tuff ring and associated rhyolitic flow (0.38 Ma; rhyolitic domes of south Antimilos have the same age); (3) the Fyriplaka rhyolitic tuff ring and associated flows within 
the N-S-trending Zephyria graben (90 ka from K-Ar dating; 19 ka from fission track dating). Today, a large hydrothermal system dominates central and eastern Milos. Many hydrothermal explosions from this system have occurred, both prior to and since the last magmatic eruption. These events are recorded by thick accumulations of debris flow deposits that are rich in basement schist fragments throughout central-eastern Milos. Hydrothermal explosions also occurred in the first and second centuries AD in southern Milos.

\section{Christiana-Santorini-Kolumbo Volcanic Field}

The Christiana-Santorini-Kolumbo volcanic field dominates the central sector of the arc (FIG. 1F). It consists of a line of volcanoes that run SW to NE: the extinct Christiana Volcano, Santorini Volcano, Kolumbo Seamount, and 22 cones of the submarine Kolumbo chain. The eroded remnants of Christiana (Christiani, Askania, and Eschati islands) are composed of as yet undated andesitic to dacitic lava domes and flows with silicic tuffs. Santorini is composed of three islands (Thera, Therasia, and Aspronisi) arranged in a dissected ring around a flooded caldera containing the post-caldera islands of Palea and Nea Kameni (FIG. 3F). Santorini is one of the most explosive arc volcanoes in the world. Activity began 0.65 Ma with submarine, then subaerial, extrusive eruptions, becoming highly explosive about $0.25 \mathrm{Ma}$. Since then, over a hundred explosive eruptions have occurred, with at least twelve of Plinian intensity (FIG. 4). Many eruptions discharged pyroclastic flows into the sea, and at least four caused caldera collapses. The last caldera-forming eruption was the Late Bronze Age eruption of $\sim 1,630$ BCE (also called the "Minoan" eruption). Palaea and Nea Kameni are the subaerial summits of a $470 \mathrm{~m}$ high intracaldera edifice built up since the Late Bronze Age eruption through many submarine, then (from 197 BCE) subaerial, eruptions of dacitic magma (Pyle and Elliot 2006). The nine historically recorded eruptions of Kameni between 197 BC and AD 1950 have involved extrusive and weakly explosive activity. Kolumbo Seamount $6 \mathrm{~km}$ NE of Santorini also has a long history of explosive activity known from marine seismic records, the last in 1650 (Cantner et al. 2014)

\section{Kos-Nisyros-Yali Volcanic Field}

The Kos-Nisyros-Yali volcanic field (that also includes the islands of Pahia, Pyrgussa and Strongyli) is the easternmost of the arc (FIG. 1C). The earliest known activity of the field (3.41.6 Ma) built a dacitic-rhyolitic dome complex in southern Kos, and possibly also on Pyrgussa and Pahia islets west of Nisyros. Eruption of rhyolitic magma about 0.5 Ma formed the Kefalos tuff ring (FIG. 3D) and the Zini obsidian dome, and triggered a small caldera collapse in southwest Kos. The volcanic field then built up to eruption of the $161 \mathrm{ka}$ Kos Plateau Tuff, possibly the largest known explosive eruption of the arc, which collapsed a 
large (but now tectonically deformed) submarine caldera south of Kos.

The edifices of Nisyros and Yali have been constructed in and around the submarine caldera since the Kos Plateau Tuff eruption. Nisyros is a $700 \mathrm{~m}$ high, composite volcano with a 3.6 $\mathrm{km}$ diameter caldera (Dietrich and Lagios 2018). Following a long period of cone construction, Nisyros had two caldera-forming explosive eruptions that produced the Lower and Upper Pumices, the age of the latter being $~ 47$ ka. Following the Upper Pumice eruption, six silicic lava domes were discharged, five inside the caldera and one outside (Braschi et al. 2014) (FIG. 3E). At least the youngest of the intracaldera domes postdates the Yali-2 pumice (32-33 ka) (FIG. 4).

Between 1873 and 1887, hydrothermal explosions created three small craters on the floor of Nisyros caldera (Dietrich and Lagios 2018). The presence of other, older hydrothermal explosion craters shows that this type of activity has been frequent over the past few thousand years. The island is today the site of intense hydrothermal activity that feeds a high-temperature geothermal field having many fumaroles and hot springs.

Yali islet is the youngest centre of the volcanic field. The SW part is the uplifted remnant of a submarine rhyolitic pumice cone (Yali-1 Pumice), whereas the NE part consists of younger pumice (Yali-2 Pumice) and obsidian lava domes. Agios Antonios islet emerges between the two hills of Yali and consists of earlier dacitic lavas. The age of Yali 1 is unknown, but Yali 2 pumice cone probably dates from 32-33 ka (see below) and the obsidian from $24 \mathrm{ka}$. An uppermost pumice layer may be prehistoric in age. Strongyli is a steep andesitic cone rising from the $500 \mathrm{~m}$ deep seafloor to its top at $120 \mathrm{~m}$ above sea level. The Yali-2 pumice covers the floor of its small central crater, dating the cone to $>33 \mathrm{ka}$.

Large portions of the arc are not affected by volcanic activity, although active faulting and crustal extension are present (Pe-Piper and Piper 2013). Marine research carried out in the area excludes the presence of additional extensive volcanic fields, although some small young submarine volcanoes may have escaped attention (Nomikou et al. 2013).

\section{THE MARINE TEPHRA RECORD OF THE SOUTH AEGEAN VOLCANIC ARC}

Distal ash deposits (tephra layers) preserved in Eastern Mediterranean marine sediments complement on-land eruptive records and provide additional chronological information on the volcanic history of the volcanic arc. These extra source constraints are particularly important in the Aegean arc, because many of its magmas lack sanidine crystals and radiometric dating is mainly limited to whole rocks and groundmasses. Indirect dating of eruptions through their correlative tephra layers in marine sequences has been particularly 
fruitful for Santorini, Kos, Nisyros and Yali volcanoes (FIG. 4). Major and trace element analyses of tephra glasses allow correlation with on-land volcanic sequences. Dates from marine sequences can thereby be imported into on-land volcanic stratigraphies, and viceversa, providing a full and mutually consistent chronology of volcanism (FIG. 4).

Ages of individual deep-marine tephra layers can be estimated either by radiocarbon dating of overlying or underlying sediments, or by tuning the accompanying oxygen isotope record to nearby, well dated, marine sections or even speleothem records on land. Dates of sapropel layers (organic-rich deposits) in the marine sediments of the Eastern Mediterranean (FIG. 4) also aid in dating (Grant et al. 2012). Previously dated tephra layers from Italian volcanoes, notably those associated with the eruption of the Campanian Ignimbrite $(\sim 39 \mathrm{ka})$ and the P11 Pantelleria ( 133 ka; "P" standing for "Pantelleria") eruption, provide additional time markers. In recent years, studies of visible tephra layers have been augmented by discoveries of so-called crypto-tephra layers with concentrations of glass shards too low to be detected with the naked eye.

We now have a tephrochronological record of many eruptions of the Aegean arc volcanoes (FIG. 4), particularly those of the large volcanic fields of the central and eastern arc (Aksu et al. 2008; Satow et al. 2015; Koutrouli et al. 2018). Nine Santorini tephra layers have been identified from as far back as 200,000 years (5 established correlations, 4 tentative) (FIG. 4), providing precise dates for eruptions that could not be well dated on land. For example, the Lower Pumice 2 eruption of Santorini gives a marine isotope stratigraphy age of $\sim 175 \mathrm{ka}$, which is consistent with $\mathrm{K}-\mathrm{Ar}$ ages of underlying and overlying lavas found on land (FIG. 4). Deep-sea tephra from the Upper Pumice eruption of Nisyros allow us to constrain the eruption age at $\sim 47 \mathrm{ka}$ (Tomlinson et al. 2012); the age of the Yali-2 eruption is 32-33 ka (Satow et al. 2015). These eruptions provide time constraints on the evolving dynamics of these volcanoes, such as the durations of periods of quiescence or lava effusion (FIG. 4). Little is known of the Aegean tephrochronological record before $200 \mathrm{ka}$, due to the paucity of long enough sediment cores. However, Van Hinsbergen et al. (2004) related Pliocene tephra layers to the onset of volcanism on Milos and Aegina, demonstrating the potential use of marine tephra even before the Pleistocene.

Marine tephra layers from the Aegean arc have been identified in the Eastern Mediterranean and Aegean seas, and even in the Black Sea. If preservation of a given tephra layer is good, then construction of an isopach map can enable volcanologists to refine eruptive volumes, as has been done for the Late Bronze Age and Cape Riva eruptions of Santorini, as well as the Kos Plateau Tuff eruption of Kos at $161 \mathrm{ka}$. The large geographical range of tephra layers means they can also be employed to address regional hypotheses that go beyond local 
studies of individual volcanic systems. The integration of Aegean marine tephra records with contemporaneous tephra records of Italian volcanoes provides the opportunity to explore the interplay of tectonics and volcanism at the scale of the entire Mediterranean. The same marine sediments that contain the tephra layers also record climate and sea-level variations (Grant et al. 2012), allowing us to investigate the effects of sea-level changes on volcanic activity or of the climatic consequences of large eruptions. The Aegean arc marine record is a natural laboratory for interdisciplinary studies, but it has not yet been fully exploited.

\section{EVOLUTION OF THE VOLCANIC ARC THROUGH TIME}

The onset of volcanic activity in the South Aegean Volcanic Arc was at 4.7 Ma at the AeginaPoros-Methana volcanic field. This was followed at 4.5 Ma for Milos and 3.4 Ma for the KosNisyros-Yali volcanic field. The oldest volcanic products recorded at Christiana-SantoriniKolumbo are only 1 Ma (FIG. 2). It is possible that this is an artefact of the lack of dates for Christiana or the presence of early Santorini products under water. If volcanism indeed began later in the central sector of the arc than in the western and eastern extremities, then a tectonic cause has yet to be identified.

\section{RELATIONSHIP BETWEEN VOLCANISM AND TECTONICS ALONG THE ARC}

The western sector of the South Aegean arc is characterized by smaller, commonly monogenetic, centres (Sousaki, Aegina-Poros-Methana, Milos), whereas the central sector (Christiana-Santorini-Kolumbo) and eastern sector (Kos-Nisyros-Yali) are both characterized by large composite volcanoes with calderas. This suggests higher mantle magma production rates and/or crustal stress conditions more favourable to the formation of large, shallow magma chambers in the central and eastern sectors than further west.

A strong relationship between surface faulting and volcanic activity exists along the arc. The volcanic fields are restricted to five zones elongated in a roughly arc-normal direction: $\mathrm{E}-\mathrm{W}$ at Sousaki, ENE-WSW at Milos, NE-SW at Christiana-Santorini-Kolumbo, and NW-SE at Kos-Nisyros-Yali. On a local scale, vent locations and edifice shapes are strongly influenced by regional normal faults, sometimes in multiple sets, that reflect arc-parallel extensional stress regimes (FIG. 1). For example, at Christiana-Santorini-Kolumbo, the volcanic field lies within a series of en echelon NE-SW grabens, and the present-day active centres of Kameni and Kolumbo lie on faults related to this system. Historical vents on Nea Kameni lie within a zone that is $600 \mathrm{~m}$ wide and trends $65^{\circ} \mathrm{NE}$, parallel to the regional trend. Epicentres of seismic events during the 2011-2012 unrest period at Santorini lay on this same lineament (Vougioukalakis et al. 2016). Three different structural contexts have been proposed for three of the arc volcanoes (Kokkalas and Aydin 2013): 1) the tip zone of a NE-trending 
divergent dextral strike-slip zone (Milos); 2) an overlap zone between oblique-normal faults associated with an extensional strike-slip duplex (Santorini); 3) a relay zone between strikeslip and oblique-normal fault segments (Nisyros). Low-angle extensional shear zones deeper in the crust may also provide pathways for ascending magmas, as clearly illustrated by exhumed Aegean granitoid plutons of Miocene age (Kokkalas and Aydin 2013). The presence of magma bodies in the crust may change the stress states on faults, causing the complex feedbacks between magma intrusion and tectonics that were observed at ChristianaSantorini-Kolumbo in 2011-2012 (Feuillet 2012).

Orientations of vent alignments along the arc have changed with time. In the Milos and KosNisyros-Yali fields, vent orientations changed from the Pliocene to the Quaternary: from NESW to N-S in Milos, and from NW-SE to NE-SW in Kos-Nisyros-Yali. At Sousaki and AeginaMethana-Poros vent aligments changed from E-W during the early Pliocene to NW-SE during the late Quaternary. There is also evidence for vent migration with time at some of the volcanic fields, presumably due to time-varying crustal stress regimes: from $\mathrm{W}$ to $\mathrm{E}$ at Sousaki, from ENE to WSW at Aegina-Poros-Methana, from both NE and SW to the centre of the field at Milos, and from SW to NE at both Christiana-Santorini-Kolumbo and KosNisyros-Yali.

\section{NATURAL RESOURCES OF THE VOLCANIC ARC}

The volcanoes of the arc provide us with a range of natural mineral resources. On Milos, mining of obsidian started about 8,000 BCE, this obsidian being exported throughout Greece and Asia Minor for fabricating tools and weapons. Kaolin has been exploited at Milos since the Bronze Age for pottery and pharmaceutical uses, and sulfur and manganese have long been mined. On Santorini, quarrying of the thick tuffs from the Late Bronze Age eruption commenced in the $19^{\text {th }}$ century; by the 1940 s, it had become a major industry employing 200-300 people. When mixed with lime, the Late Bronze Age tuff makes a cement that was widely exported, it being used, for example, to build the Suez Canal (Egypt) and the ports of Alexandria (Egypt) and Constanţa (Romania). The quarries were closed for environmental reasons at the end of the 1980s. Yali pumice is quarried and exported to Europe, Africa, and North America.

The volcanic arc offers great potential for geothermal power, although it has not yet been exploited (Papachristou et al. 2016). Milos possesses proven resources with shallow reservoirs up to $90-100^{\circ} \mathrm{C}$, deep reservoirs up to $240{ }^{\circ} \mathrm{C}$, and an estimated potential of $>200$ MWe (Mega-Watt electricity output). Indeed a 2 MWe plant was opened on Milos in 1986, but it closed in 1989 following technical and environmental problems. Nisyros also has 
confirmed high-temperature $\left(>500{ }^{\circ} \mathrm{C}\right.$ at $1,800 \mathrm{~m}$ depth) geothermal potential $(>4 \mathrm{MWe}$ confirmed through drilling, $>50$ MWe estimated) that could satisfy the power needs of the island and part of Kos. On Santorini, geothermal resources have been located in on-land drill holes with reservoir temperatures up to $65^{\circ} \mathrm{C}$ at depths of up to $250 \mathrm{~m}$. Higher-temperature fluids are present below Kolumbo crater, and probably below Santorini caldera, but are not accessible for exploitation.

\section{VOLCANIC HAZARD AND RISK ALONG THE VOLCANIC ARC}

Three volcanoes of the arc have had historically documented magmatic eruptions: the andesitic dome complex of Methana ( 230 BCE), the dacitic intracaldera Kameni Volcano at Santorini (197 BCE, AD 46-47, 726, 1570-1573, 1707-1711, 1866-1870, 1925-1928, 19391941, and 1950), and the rhyolitic Kolumbo Volcano (1650). The eruptions at Methana and Kameni were largely effusive, although the AD 726 eruption of Kameni was probably subPlinian in intensity (Pyle and Elliot 2006). The eruption of Kolumbo in 1650 discharged 2 $\mathrm{km}^{3}$ of gas-charged rhyolitic magma and caused the deaths of over 70 people and many animals on Santorini (Cantner et al. 2014). Several hydrothermal explosions have taken place in Nisyros caldera in historical times, the last in 1887, and Milos had hydrothermal explosions in the $1^{\text {st }}$ and $2^{\text {nd }}$ centuries AD. Probably all five volcanic fields of the South Aegean Volcanic Arc remain potentially active. Established hydrothermal systems at Milos, Santorini, Kolumbo and Nisyros volcanoes probably reflect the presence of shallow-crustal magma reservoirs, as confirmed by seismic tomography at Santorini and Kolumbo (Dimitriadis et al. 2010). Recent seismic unrest at Nisyros in 1995-1997 (Gottsman et al. 2007) and Santorini in 2011-2012 (Parks et al. 2015) serve as reminders of the potential threat of eruption at these tourist centres of the Eastern Mediterranean. Potential hazards from the Aegean arc include high ash plumes that threaten aviation traffic (Jenkins et al. 2015), and pyroclastic flows and clouds of toxic gases that threaten populated areas around the volcanoes and on neighbouring islands. In addition to earthquake-related tsunamis, tsunamis generated by submarine eruptions along the arc (such as those generated by Kolumbo seamount in 1650) (Cantner et al. 2014) remain a possibility.

Future activity of the Aegean volcanoes is hard to predict (Vougioukalakis and Fytikas 2005). Possible eruptive scenarios at the western volcanic fields include the eruption of lava domes, pumice eruptions, or explosions of hydrothermal systems. The most likely event at Santorini is a lava eruption similar to that of 1925-1928, but an explosive eruption like AD 726, with a potential impact on aviation traffic, cannot be ruled out (Vougioukalakis et al. 2016; Jenkins et al. 2015). An eruption of Kolumbo Seamount is possible, although it is unlikely to be as large as that of 1650 . On Nisyros, the most probable event is a hydrothermal explosion within 
the caldera, a popular tourist destination (Kinvig et al. 2010; Venturi et al. 2018). However, a worst-case-scenario phreatomagmatic eruption at Nisyros would threaten not only the island's inhabitants, but also those of Kos. The very young (probably prehistoric) age of the last explosive eruption of Yali (FIG. 4) also makes this centre a threat. The probability of a large explosive eruption similar to that of Santorini in 1630 BCE or of Kos at $161 \mathrm{ka}$ anywhere along the Aegean arc in the foreseeable future is very low, but not zero. Of all the arc volcanoes, Santorini is the only one with a volcano observatory and modern multiparameter (seismics, deformation, gas) monitoring system that functioned successfully during the 2011-2012 unrest crisis (Tassi et al. 2013). Neither Methana, Milos or Nisyros are adequately monitored.

\section{ACKNOWLEDGMENTS}

\section{REFERENCES}

Aksu AE, Jenner G, Hiscott RN, Işler EB (2008) Occurrence, stratigraphy and geochemistry of late Quaternary tephra layers in the Aegean Sea and Marmara Sea. Marine Geology 252: 174-192

Braschi E, Francalanci L, Tommasini S, Vougioukalakis GE (2014) Unraveling the hidden origin and migration of plagioclase phenocrysts by in situ $\mathrm{Sr}$ isotopes: the case of final dome activity at Nisyros volcano, Greece. Contributions to Mineralogy and Petrology 167, doi: 10.1007/s00410-014-0988-4

Cantner K, Carey S, Nomikou P (2014) Integrated volcanologic and petrologic analysis of the 1650 AD eruption of Kolumbo submarine volcano, Greece. Journal of Volcanology and Geothermal Research 269: 28-43

Dietrich VJ, Lagios E (eds) (2018) Nisyros Volcano: The Kos - Yali - Nisyros Volcanic Field. Springer International Publishing, $339 \mathrm{pp}$.

Dimitriadis I and 6 coauthors (2010) P and S velocity structures of the Santorini-Coloumbo volcanic system (Aegean Sea, Greece) obtained by non-linear inversion of travel times and its tectonic implications. Journal of Volcanology and Geothermal Research 195: $13-30$

Feuillet N (2013) The 2011-2012 unrest at Santorini rift: stress interaction between active faulting and volcanism. Geophysical Research Letters 40: 3532-3537

Foutrakis PM, Anastasakis G (2018) The active submarine NW termination of the South Aegean Active Volcanic Arc: the submarine Pausanias Volcanic Field. Journal of Volcanology and Geothermal Research 357: 399-417

Fytikas M, Vougioukalakis GE (eds) (2005) The South Aegean Active Volcanic Arc. Present Knowledge and Future Perspectives. Developments of Volcanology 7, Elsevier Ltd., $381 \mathrm{pp}$ 
Francalanci L, Vougioukalakis GE, Fytikas M (2007) Petrology and volcanology of Kimolos and Polyegos volcanoes within the context of the South Aegean arc, Greece. In: Beccaluva L, Bianchini G, Wilson M (eds) Cenozoic Volcanism in the Mediterranean Area. Geological Society of America Special Paper 418, pp 33-66

Gottsmann J and 5 coauthors (2007) Oscillations in hydrothermal systems as a source of periodic unrest at caldera volcanoes: multiparameter insights from Nisyros, Greece. Geophysical Research Letters 34, doi: 10.1029/2007GL029594

Grant KM and 7 coauthors (2012) Rapid coupling between ice volume and polar temperature over the past 150,000 years. Nature 491: 744-747

Jenkins SF and 7 coauthors (2015) Rapid emergency assessment of ash and gas hazard for future eruptions at Santorini Volcano, Greece. Journal of Applied Volcanology 4, doi: 10.1186/s13617-015-0033-y

Kinvig HS, Winson A, Gottsmann J (2010) Analysis of volcanic threat from Nisyros Island, Greece, with implications for aviation and population exposure. Natural Hazards and Earth System Sciences 10: 1101-1113

Kokkalas S, Aydin A (2013) Is there a link between faulting and magmatism in the southcentral Aegean Sea? Geological Magazine 150: 193-224

Koutrouli A and 6 coauthors (2018) The early to mid-Holocene marine tephrostratigraphic record in the Nisyros-Yali-Kos volcanic center, SE Aegean Sea. Journal of Volcanology and Geothermal Research 366: 96-111

Morris A (2000) Magnetic fabric and palaeomagnetic analyses of the Plio-Quaternary calcalkaline series of Aegina Island, South Aegean volcanic arc, Greece. Earth and Planetary Science Letters 176: 91-105

Nomikou P, Papanikolaou D, Alexandri M, Sakellariou D, Rousakis G (2013) Submarine volcanoes along the Aegean volcanic arc. Tectonophysics 597-598: 123-146

Papachristou M and 5 coauthors (2016). Geothermal energy use, country update for Greece. European Geothermal Congress 2016, Strasbourg, France, 19-24 Sept 2016. Extended conference abstract, $14 \mathrm{pp}$

Parks MM and 10 others (2015) From quiescence to unrest: 20 years of satellite geodetic measurements at Santorini volcano, Greece. Journal of Geophysical Research: Solid Earth 120: 1309-1328

Pe-Piper G, Piper DJW (2007) Neogene back-arc volcanism of the Aegean: new insights into the relationship between magmatism and tectonics. In: Beccaluva L, Bianchini G, Wilson M (eds) Cenozoic Volcanism in the Mediterranean Area. Geological Society of America Special Paper 418, pp 17-31

Pe-Piper G, Piper DJW (2013) The effect of changing regional tectonics on an arc volcano: Methana, Greece. Journal of Volcanology and Geothermal Research 260: 146-163

Pyle DM, Elliott JR (2006) Quantitative morphology, recent evolution, and future activity of the Kameni Islands volcano, Santorini, Greece. Geosphere 2: 253-268

Satow C and 11 coauthors (2015) A new contribution to the late Quaternary 
tephrostratigraphy of the Mediterranean: Aegean Sea core LC21. Quaternary Science Reviews 117: 96-112

Stewart AL, McPhie J (2006) Facies architecture and Late Pliocene-Pleistocene evolution of a felsic volcanic island, Milos, Greece. Bulletin of Volcanology 68: 703-726

Tassi F and 8 coauthors (2013) Geochemical and isotopic changes in the fumarolic and submerged gas discharges during the 2011-2012 unrest at Santorini caldera (Greece). Bulletin of Volcanology 75, doi: 10.1007/s00445-013-0711-8

Tomlinson ET and 6 coauthors (2012) The Upper and Lower Nisyros Pumices: revisions to the Mediterranean tephrostratigraphic record based on micron-beam glass geochemistry. Journal of Volcanology and Geothermal Research 243-244: 69-80

van Hinsbergen DJJ and 6 coauthors (2004) Vertical motions in the Aegean volcanic arc: evidence for rapid subsidence preceding volcanic activity on Milos and Aegina. Marine Geology 209: 329-345

Venturi S and 10 coauthors (2018) Active hydrothermal fluids circulation triggering smallscale collapse events: the case of the 2001-2002 fissure in the Lakki Plain (Nisyros Island, Aegean Sea, Greece). Natural Hazards 93: 601-626

Vougioukalakis GE, Fytikas M (2005) Volcanic hazards in the Aegean area, relative risk evaluation, monitoring and present state of the active volcanic centers. In: Fytikas M and Vougioukalakis GE (eds) The South Aegean Active Volcanic Arc: Present Knowledge and Future Perspectives. Developments in Volcanology 7, Elsevier, pp 161-183

Vougioukalakis G and 5 coauthors (2016) Volcanic hazard assessment at Santorini Volcano. A review and a synthesis in the light of the 2011-2012 Santorini unrest. Bulletin of the Geological Society of Greece 50: 274-284

\section{FIGURE CAPTIONS}

Figure 1 (A) The South Aegean Volcanic Arc, with the individual eruptive centres of its five volcanic fields marked as red triangles. White arrow shows the direction of subduction of the African plate beneath the Aegean Sea. (B-F) Zooms of the five volcanic fields. Stars represent subaerial vents and crosses represent submarine vents, coloured according to age: Pliocene (yellow stars and crosses), Quaternary (blue stars and crosses), Holocene (red stars and crosses). Red lines are faults or tectonic lineaments.

Figure 2 Graph of age versus west-to-east geographic distribution of the South Aegean Volcanic Arc volcanoes. Ages are from radiometric dating (squares), field observations and correlations (lines), and biostratigraphic or magnetostratigraphic data (circles). Calderaforming eruptions are shown as stars. Volcanoes with historical eruptions are shown with cones: solid cones for magmatic eruptions, and hollow cones for phreatic eruptions.
Commented [JR1]: Georges - to make it easier for the reader to navigate this figure we suggest the following changes:

1. Add labels (B-F) to panel A that correspond to the other panels

2. Change the symbol of the "crosses". We found the 4sided stars were difficult to distinguish from the 5-sided stars.

SEE FIGURE ATTACHED TO EMAIL

Commented [JR2]: No circles shown. Do you mean stars $(*)$ ?

Commented [PR3]: No explanation what the colours (blue green, orange, red) of the graph mean. Presumably something geographic? Please explain. [Note that, as given, the relation of the colours to the named volcanoes and the 'east-west' axis is not evident - there must be something else being alluded to in the use of the colours]. 
Figure 3 Volcanic deposits of the South Aegean Volcanic Arc. (A) The Kameni Hora historical (230 BCE) dacitic lava dome and flows, NW Methana Peninsula. Aegina Island is in left middle distance. (B) The Geronikola tuff ring deposits (pale coloured unit, marked by arrows) and the basaltic andesitic lava flows that overly them and that fill the tuff ring crater. Northeast coast of Kimolos. (C) Rhyolitic submarine tuffs (2.7 Ma) at Sarakinike, north coast of Milos. (D) Rhyolitic pyroclastic density current deposits of the Kefalos tuff ring ( $\sim 0.5 \mathrm{Ma}$ ) near Kamari, southwest Kos. (E) Nikia rhyolitic lava flow, Avlaki, SE coast of Nisyros. (F) The AD 726 lava lobe, northeast cliff of Palea Kameni, Santorini.(G) Nisyros caldera viewed from the north-northeast. On the right in the distance, the post-caldera domes fill half of the caldera depression.

Figure 4 Schematic Late Quaternary marine stratigraphy for the Aegean, showing biostratigraphic zones, sapropel horizons, and tephra layers correlated to Aegean volcanoes. Tephra from Santorini are shown as red lines; those from the Kos-Nisyros-Yali system as blue lines. Established correlations are those supported by geochemical matching of the glass component of the marine tephras to on-land volcanic deposits. If other Aegean volcanoes were active during the time period shown, they do not appear to have produced explosive eruptions large enough to preserve tephra in the marine record. All events are shown against an established chronology defined by prominent sapropels (Grant et al. 2012). The marine tephra layers ( $Z 2, V 3$ etc.) are named by their position with respect to established biostratigraphic zones (Aksu et al. 2008; Satow et al. 2015). Tentative correlations concern tephra layers that have been discovered more recently and which do not fit the established nomenclature and/or have not yet been matched to specific eruptions (Aksu et al. 2008, Grant et al. 2012, Satowet al. 2015; Koutrouliet al. 2018). Tephra layers from Italian sources are also present in Aegean sediments, but these are not shown here. Numbered references are as follows: [1]-Aksuet al. (2008); [2]-Dietrich and Lagios (2018); [3]-Grant etal. (2012); [4] - Koutrouli et al. (2018); [5] - Satow et al. (2015); [6] - Tomlinson et al. (2012). 

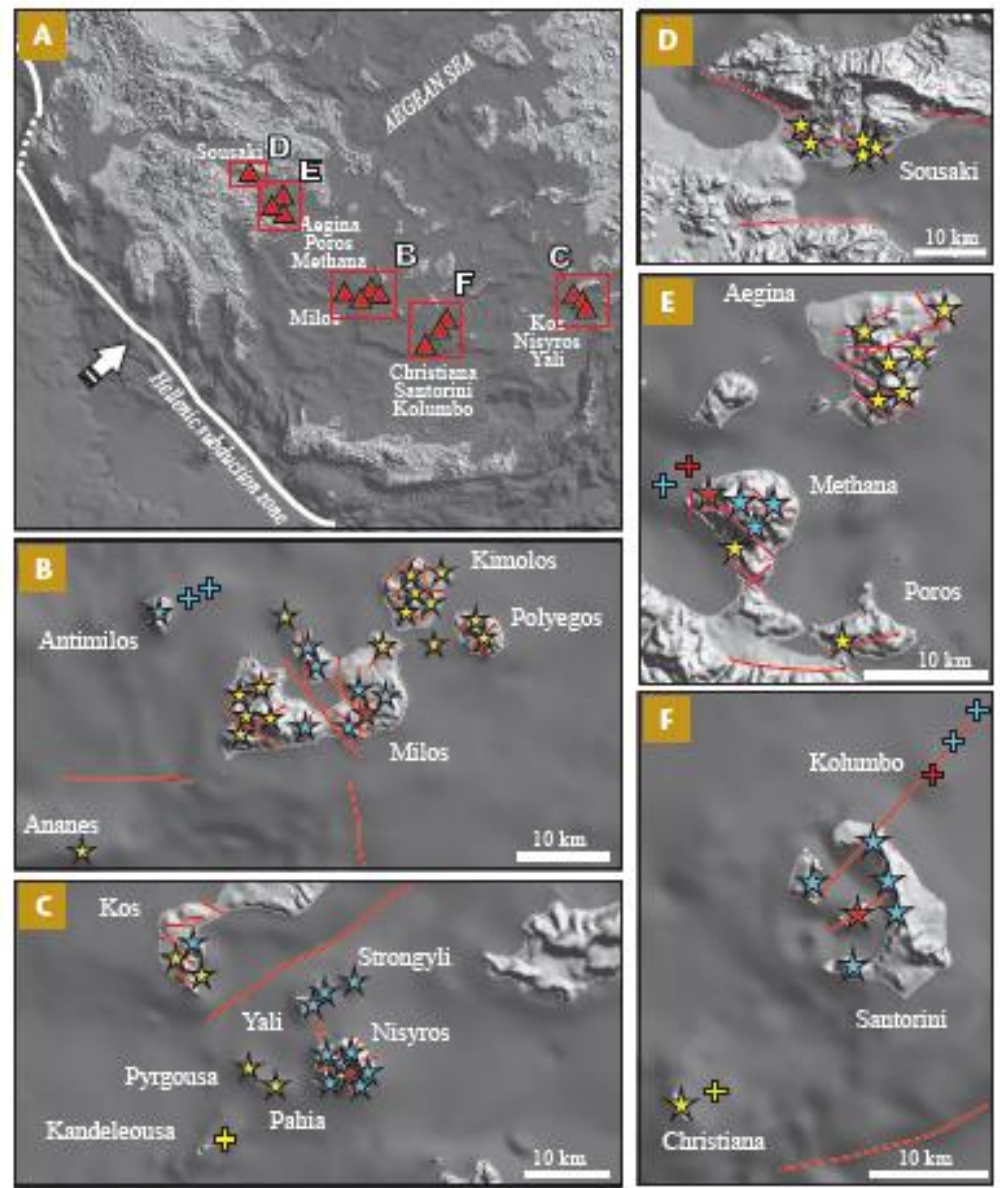

Figure 1 (A) The South Aegean volcanic arc, with the individual eruptive centres of its five volcanic fields marked as red triangles. White arrow shows the direction of subduction of the African plate beneath the Aegean Sea. (B-F) Zooms of the five volcanic fields. Stars represent subaerial vents and crosses represent submarine vents, coloured according to age: Pliocene (yellow stars and crosses), Quaternary (blue stars and crosses), Holocene (red stars and crosses). Red lines are faults or tectonic lineaments. 




Figure 2 Graph of age versus west-to-east geographic distribution of the South Aegean volcanic arc volcanoes. Ages are from radiometric dating (squares), field observations and correlations (lines), and biostratigraphic or magnetostratigraphic data (circles). Caldera-forming eruptions are shown as stars. Volcanoes with historical eruptions are shown with cones: solid cones for magmatic eruptions, and hollow cones for phreatic eruptions. Each volcanic field is shown in a different colour. 


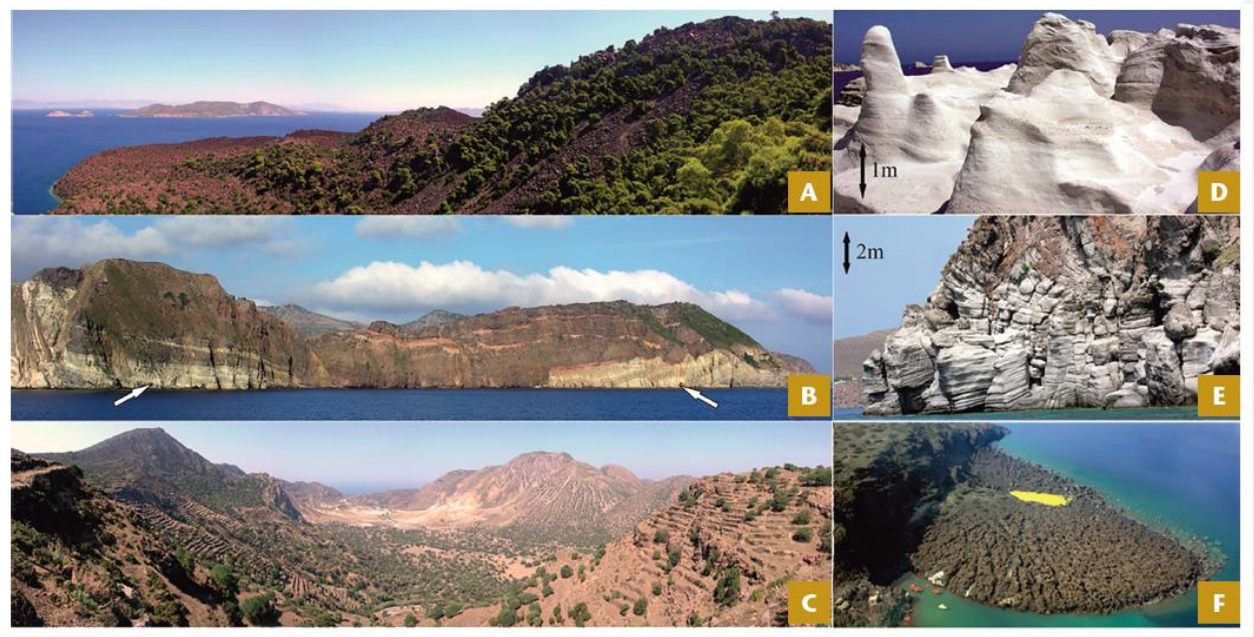

Figure 3 Volcanic deposits of the South Aegean volcanic arc. (A) The Kameni Hora historical (230 BCE) dacitic lava dome and flows, NW Methana Peninsula. Aegina Island is in left middle distance. (B) The Geronikola tuff ring deposits (pale coloured unit, marked by arrows) and the basaltic andesitic lava
flows that overly them and that fill the tuff ring crater. Northeast coast of Kimolos. (C) Nisyros caldera viewed from the north-northeast. On the right in the distance, the post-caldera domes fill half of the caldera depression. (D) Rhyolitic submarine tuffs $(2.7 \mathrm{Ma}$ ) at Sarakiniko, north coast of Milos. (E) Nikia rhyolitic lava flow, Avlaki, SE coast of Nisyros. (F) The AD 726 lava lobe, northeast cliff of 


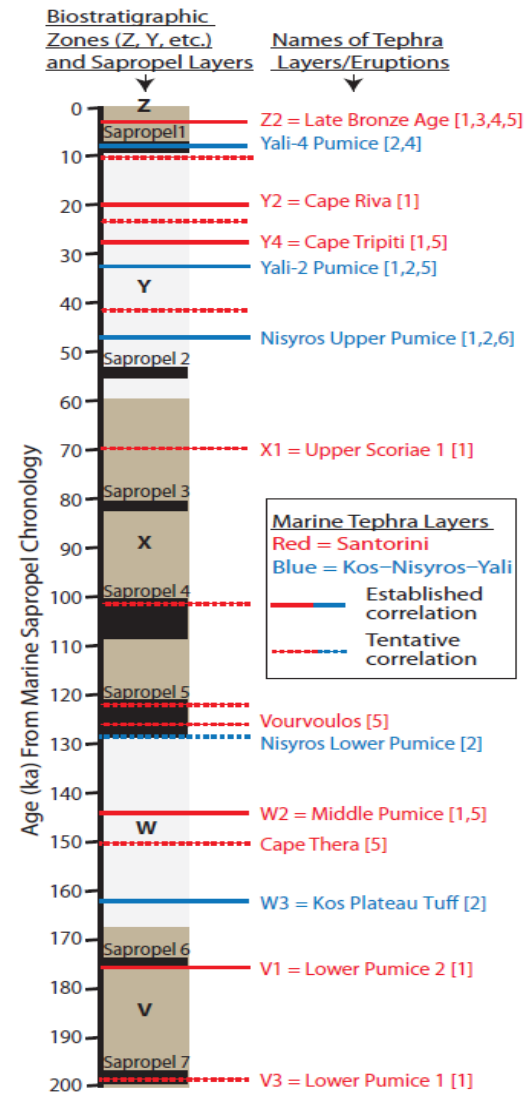

Figure 4 Schematic Late Quaternary marine stratigraphy for the Forizons, 4 Aegean, showing biostratigraphic zones, sapropel rom Santorini are shown as red lines; those from the Kos-NisyrosYali system as blue lines. Established correlations are those

supported by geochemical matching of the glass component of the marine tephras to on-land volcanic deposits. If other Aegean volcanoes were active during the time period shown, they do not appea to have produced explosive eruptions large enough to preserve tephra in the marine record. All events are shown against an established chronology defined by prominent sapropels (Grant et al. 2012). The marine tephra layers ( $Z 2, V_{3}$ etc.) are named by their position with respect to established biostratigraphic zones (Aksu et al. 2008, Satow et al. 2015). Tentative correlations concern tephra layers that have been discovered more recently and which do not fit the established nomenclature and/or have not yet been matched specific eruptions (Aksu et al. 2008, Grant et al. 2012, Satow et al. 2015, Koutrouli et al. 2018). Tephra layers from italian sources are . Numbed references are as follows. [1] - Aksu et al. (2008); [2] et al. (2018); [5] - Satow et al. (2015); [6] - Tomlinson et al. (2012). 